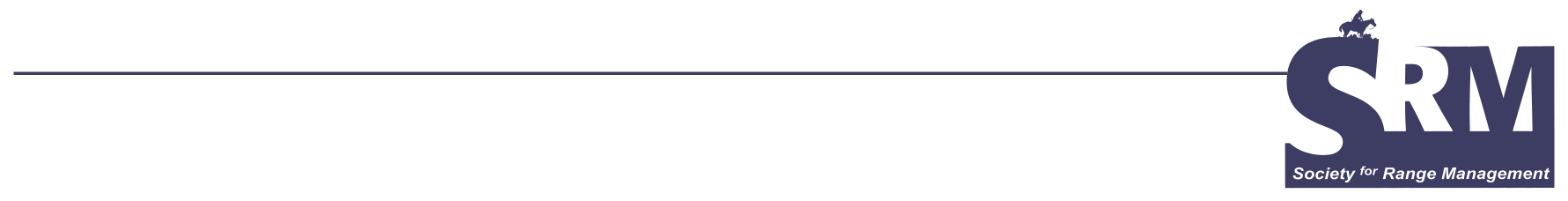

\title{
Big Bluestem Pasture in the Great Plains: An Alternative for Dryland Corn
}

Big bluestem pasture can earn more than twice as much per acre as dryland corn.

\section{By Rob Mitchell, Ken Vogel, Gary Varvel, Terry Klopfenstein, Dick Clark, and Bruce Anderson}

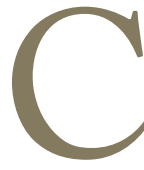

orn production and perennial grass pastures provide the foundation for the agricultural industry in the central and eastern Great Plains. Typically, many producers grow both corn and perennial grass pastures to meet livestock feed demands and to diversify the operation. For example, corn was produced on more than $37 \%$ of the total cropland, and perennial pasture comprised $49 \%$ of the land in farms in Nebraska. ${ }^{1}$ Corn was produced on an average of 7.8 million acres in Nebraska from 2000 to 2002, with 40\% being dryland (nonirrigated) corn. ${ }^{2}$

Producers seek the best long-term economic and sustainable use of cropland. The need for flexibility in the agricultural operation, long-term familiarity with a specific crop rotation, expenses associated with equipment alteration, and the uncertainty of alternative markets make it difficult for producers to implement new management practices. Perennial grasses, such as big bluestem, provide an alternative use for nonirrigated cropland in the Great Plains. Producers have little economic information available, however, to decide whether or not to convert cropland to perennial pasture. Producers need information on the economic opportunities for alternative, sustainable uses of nonirrigated cropland in diversified agricultural operations. The economic returns of dryland corn and beef production on big bluestem pastures in the eastern Great Plains are compared using production information from field trials.

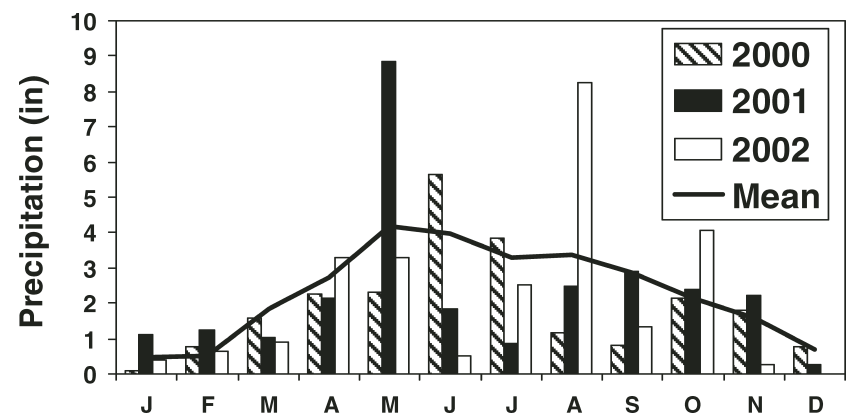

Figure 1. Monthly precipitation in 2000, 2001, 2002, and the long-term mean at Mead, NE. Annual precipitation was 23.1, 27.4, and 25.4 inches in 2000, 2001, and 2002, respectively (3). The long-term average annual precipitation is 27.7 inches.

\section{Discussion}

Annual precipitation at Mead was 23 inches in 2000, 27 inches in 2001, and 25 inches in 2002 - all below the longterm average of 28 inches $^{3}$ (Fig. 1). However, corn yield and beef production per acre were greatest in 2000 , followed by 2001, and 2002 (Table 1), demonstrating the importance of precipitation timing and distribution. In 2000, the year with the least annual precipitation of the 3 years, 4.6 inches of precipitation were received in April and May and 9.5 inches in June and July. In 2001, 11 inches of precipitation were received in April and May and 2.7 inches in June and July. In 2002, 6.6 inches of precipitation were received in April and 


\begin{tabular}{|c|c|c|c|c|c|}
\hline $\begin{array}{l}\text { Production } \\
\text { year }\end{array}$ & $\begin{array}{c}\text { Corn } \\
\left(\text { bu } \text { acre }^{-1}\right)\end{array}$ & $\begin{array}{c}\text { November } \\
\text { corn price } \\
\left(\$ \cdot \mathbf{b u}^{-1}\right)\end{array}$ & $\begin{array}{c}\text { Beef } \\
(\text { Ib-acre-1) }\end{array}$ & $\begin{array}{c}\text { June } \\
\text { steer price } \\
\left(\$ \cdot \text { cwt }^{-1}\right)\end{array}$ & $\begin{array}{c}\text { August } \\
\text { steer price } \\
\left(\$ \cdot \text { cwt }^{-1}\right)\end{array}$ \\
\hline 2000 & 98 & 1.86 & 510 & 85 & 78 \\
\hline 2001 & 80 & 1.85 & 363 & 91 & 87 \\
\hline 2002 & 78 & 2.37 & 342 & 79 & 73 \\
\hline Mean & 85 & 2.03 & 405 & 85 & 79 \\
\hline
\end{tabular}

May and 3 inches in June and July. Big bluestem emerges in April, and the period of rapid growth begins in late May; however a majority of big bluestem standing crop accumulates in June and July. Consequently, precipitation in April and May is important for early big bluestem growth, but precipitation in June and July dictates how much forage will be available for grazing.

\section{Corn}

Corn production averaged 85 bushels per acre, and corn prices averaged $\$ 2.03$ bushels per acre (Table 1). Corn production inputs averaged $\$ 127$ per acre (Table 2). The cost of seed and custom planting accounted for $33 \%$ of the average inputs, whereas weed control accounted for $28 \%$ of the average inputs. The reduced need for weed control in 2001 kept production costs low. Although no drying costs were included, custom grain drying costs $\$ 0.07$ per point of moisture removed per bushel and would significantly increase production costs. ${ }^{4}$

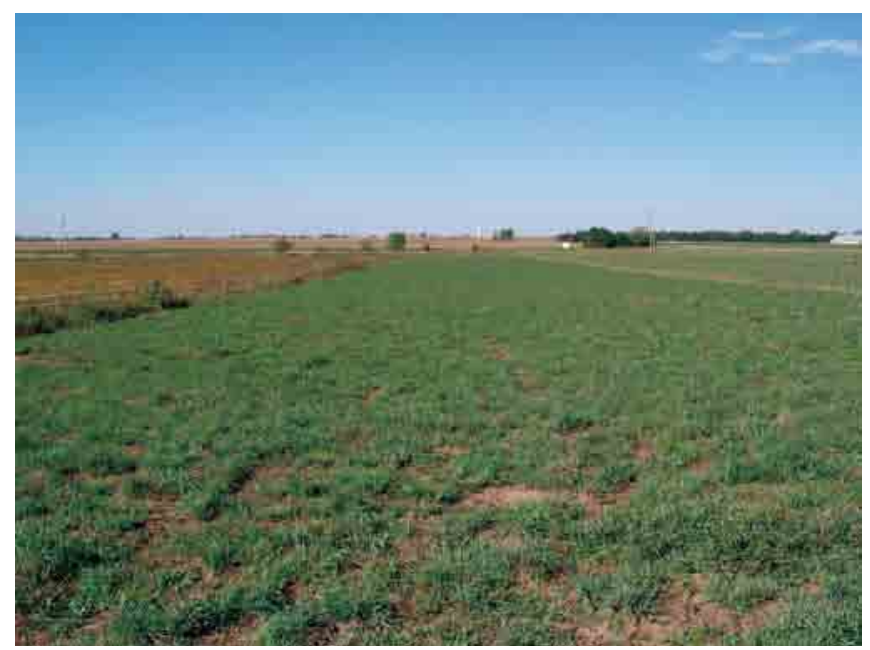

This big bluestem pasture was intentionally over-utilized during September to evaluate winter persistence and spring regrowth, which were both excellent.

\section{Big Bluestem Pasture}

Beef production averaged 405 pounds of beef per acre (Table 1). The continuous grazing period was 62 days in 2000,43 days in 2001, and 38 days in 2002. Average daily gain (ADG) for the 3 years was 2.8 pounds per head per day. Precipitation in late July and August 2001 and 2002 promoted enough grass production to provide more than 3 animal unit months (AUMs) per acre of regrowth grazing in late August, but we collected no animal production data.

Pasture establishment costs were $\$ 268$ per acre, and were amortized for 15 years at 5\% interest, resulting in a $\$ 25$ per acre amortization, based on an 80-acre pasture (Table 2). Seeding costs accounted for $17 \%$ of the pasture establishment costs, whereas fence and water development accounted for $34 \%$ and $40 \%$ of the pasture establishment costs, respectively (Table 2). Weed control costs accounted for only $5 \%$ of the pasture establishment costs, which reinforces the value of a good weed management program in the row crop before

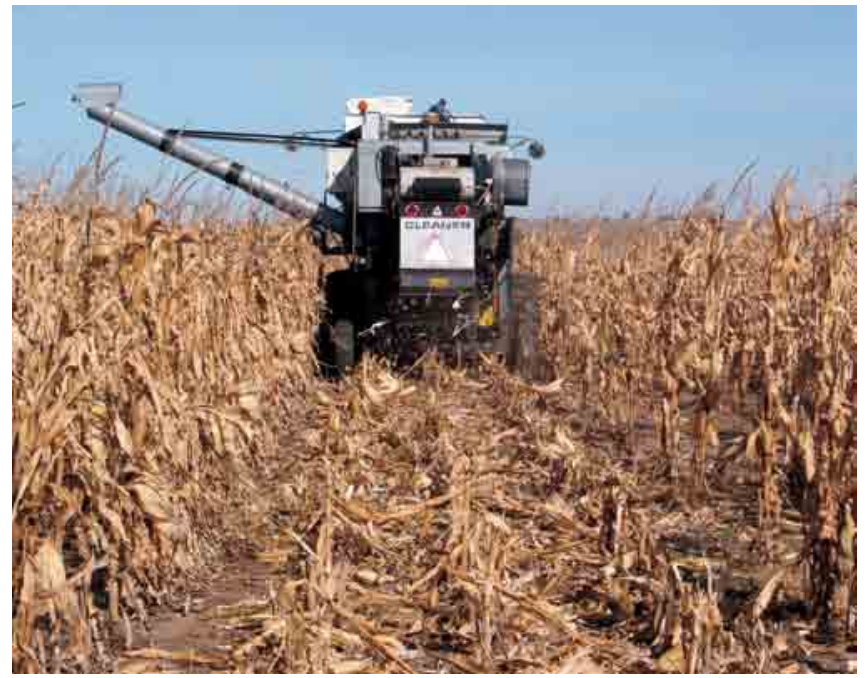

Dryland corn was harvested after extended field drying to reduce input costs. 
Table 2. Production inputs (in dollars per acre) for no-till, dryland corn and big bluestem pasture near Mead, Nebraska, in 2000, 2001, and 2002

\begin{tabular}{|l|c|c|c|c|c|}
\hline Corn & & & & \\
\hline Inputs (\$-acre-1) & & $\mathbf{2 0 0 0}$ & $\mathbf{2 0 0 1}$ & $\mathbf{2 0 0 2}$ & Mean \\
\hline Seed cost & 1 & 31.76 & 31.76 & 31.76 & 31.76 \\
\hline Custom plant $^{2}$ & 10.00 & 10.00 & 10.00 & 10.00 \\
\hline Herbicide $^{3}$ & 32.14 & 19.70 & 39.97 & 30.60 \\
\hline Custom spray $^{2}$ & 5.00 & 5.00 & 5.00 & 5.00 \\
\hline Fertilizer $^{4}$ & 23.54 & 23.54 & 23.54 & 23.54 \\
\hline Custom spread $^{2}$ & 4.50 & 4.50 & 4.50 & 4.50 \\
\hline Harvest and haul & & 22.00 & 22.00 & 22.00 & 22.00 \\
\hline Total inputs & 128.94 & 116.50 & 136.77 & 127.40 \\
\hline
\end{tabular}

\begin{tabular}{|c|c|c|c|c|c|}
\hline \multirow{2}{*}{$\begin{array}{l}\text { Big bluestem pasture } \\
\text { Inputs }\left(\$ \cdot \text { acre }^{-1}\right)^{6}\end{array}$} & \multirow[b]{2}{*}{ Establishment } & \multicolumn{4}{|c|}{ Management } \\
\hline & & 2000 & 2001 & 2002 & Mean \\
\hline Seed cost ${ }^{7}$ & 46.00 & - & - & - & - \\
\hline Custom plant ${ }^{2}$ & 10.00 & - & - & - & - \\
\hline Fence $^{8}$ & 92.06 & - & - & - & - \\
\hline Water $^{9}$ & 106.65 & - & - & - & - \\
\hline Fertilize $^{10}$ & 0 & 22.00 & 22.00 & 22.00 & 22.00 \\
\hline Custom spread ${ }^{2}$ & 0 & 4.50 & 4.50 & 4.50 & 4.50 \\
\hline Herbicide ${ }^{11}$ & 8.75 & 8.75 & 0 & 8.75 & 5.83 \\
\hline Custom spray² & 5.00 & 5.00 & 0 & 5.00 & 3.33 \\
\hline Burn $^{12}$ & 0 & 3.00 & 3.00 & 0 & 2.00 \\
\hline Annual inputs & - & 43.25 & 29.50 & 40.25 & 37.67 \\
\hline Amortization $^{13}$ & & 24.60 & 24.60 & 24.60 & 24.60 \\
\hline Total inputs & 268.46 & 67.85 & 54.10 & 64.85 & 62.26 \\
\hline
\end{tabular}

${ }^{1}$ Actual seed cost for planting 18,150 seeds per acre.

${ }^{2}$ Cost for custom service in Nebraska. ${ }^{4}$

${ }^{3}$ Actual herbicide cost for each year.

${ }^{4}$ Actual cost for 107 pounds per acre of ammonium nitrate.

${ }^{5}$ Cost to harvest ( $\$ 20$ per acre) and haul (\$2 per acre) corn in eastern Nebraska. ${ }^{7}$

${ }^{6}$ All input costs assume the establishment of an 80 -acre pasture.

${ }^{7}$ Actual seed cost for 8 pounds of pure live seed (PLS) per acre at $\$ 5.75$ per PLS pound.

${ }^{8}$ Cost for custom service assuming $\$ 4,910$ per mile on 80 acres. ${ }^{8}$

${ }^{9}$ Cost for 120 -foot well, tank, and solar pump $(\$ 8,532)$ on 80 acres. ${ }^{9}$

${ }^{10}$ Actual cost for 100 pounds per acre of ammonium nitrate.

${ }^{11}$ Actual cost of 4 ounces per acre of Plateau herbicide (BASF Corp, Research Triangle Park, NC).

${ }^{12}$ Cost to custom-burn small pastures.

${ }^{13}$ Establishment cost amortized for 15 years at $5 \%$ interest on 80 acres.

grass establishment. Annual pasture inputs ranged from $\$ 30$ per acre to $\$ 43$ per acre and averaged $\$ 38$ per acre across years. The cost of fertilization accounted for at least $61 \%$ of the annual inputs (Table 2). Total pasture inputs ranged from $\$ 54$ per acre to $\$ 68$ per acre and averaged $\$ 62$ per acre. The amortized costs of pasture establishment were less than the annual inputs required for pasture management.

Net Returns

The difference in net return between 2000 and 2002 reinforces 
Table 3. Net return (in dollars per acre) for no-till, dryland corn and big bluestem pasture near Mead, Nebraska, in 2000, 2001, and 2002

\begin{tabular}{|l|c|c|c|c|}
\hline Corn & $\mathbf{2 0 0 0}$ & $\mathbf{2 0 0 1}$ & $\mathbf{2 0 0 2}$ & Mean \\
\hline Yield $\left(\mathrm{bu} \cdot \mathrm{acre}^{-1}\right)$ & 98 & 80 & 78 & 85.9 \\
\hline Market price $\left(\$ \cdot \mathrm{bu}^{-1}\right)^{1}$ & 1.86 & 1.85 & 2.37 & 2.03 \\
\hline Gross return $\left(\$ \cdot \mathrm{acre}^{-1}\right)$ & 182 & 147 & 184 & 171 \\
\hline Stalks $\left(\$ \cdot \mathrm{acre}^{-1}\right)^{2}$ & 5 & 5 & 5 & 5 \\
\hline Total gross return $\left(\$ \cdot \mathrm{acre}^{-1}\right)$ & 187 & 152 & 189 & 176 \\
\hline Inputs $\left(\$ \cdot \mathrm{acre}^{-1}\right)^{3}$ & 129 & 117 & 137 & 127 \\
\hline Net return $\left(\$ \cdot \mathrm{acre}^{-1}\right)$ & 58 & 36 & 52 & 49 \\
\hline
\end{tabular}

\begin{tabular}{|c|c|c|c|c|}
\hline Big bluestem pasture & & & & \\
\hline Animal weight on (lb·acre $\left.{ }^{-1}\right)$ & 2,358 & 2,472 & 2,544 & \\
\hline Market price on $\left(\$ \cdot \mathrm{cwt}^{-1}\right)^{4}$ & 85.33 & 90.50 & 78.52 & 84.78 \\
\hline Animal value on $\left(\$ \cdot\right.$ acre $\left.^{-1}\right)$ & $2,012.08$ & $2,237.16$ & $1,997.55$ & \\
\hline Animal weight off $\left(\mathrm{lb} \cdot \mathrm{acre}^{-1}\right)$ & 2,868 & 2,835 & 2,886 & \\
\hline Market price off $\left(\$ \cdot c w t^{-1}\right)^{5}$ & 77.99 & 86.59 & 72.70 & 79.09 \\
\hline Animal value off $\left(\$ \cdot a^{2} e^{-1}\right)$ & $2,236.75$ & $2,454.83$ & $2,098.12$ & \\
\hline Gross return $\left(\$ \cdot\right.$ acre $\left.^{-1}\right)$ & 224.67 & 217.67 & 100.57 & \\
\hline Inputs $\left(\$ \cdot\right.$ acre $\left.^{-1}\right)$ & 67.85 & 54.10 & 64.85 & 62.26 \\
\hline Net return $\left(\$ \cdot a^{2} e^{-1}\right)$ & 156.82 & 163.57 & 35.72 & 118.70 \\
\hline Beef gain $\left(\mathrm{Ib} \cdot \mathrm{acre}^{-1}\right)$ & 510 & 363 & 342 & 405 \\
\hline Net return $\mathrm{Ib}^{-1}$ of gain $(\$)$ & 0.31 & 0.48 & 0.10 & 0.30 \\
\hline
\end{tabular}

bu indicates bushels; \$, US dollars; lb, pounds; cwt, hundredweight.

${ }^{1}$ Average November corn price for Nebraska each year. ${ }^{6}$

${ }^{2}$ Value (in dollars per acre) of corn stalks for winter grazing.

${ }^{3}$ Assumes crop is field-dried and marketed at harvest so no drying or storage costs are included.

${ }^{4}$ Average June (on) steer prices for each weight class in Nebraska each year provided by Livestock Marketing Information

Center, Lakewood, CO.

${ }^{5}$ Average August (off) steer prices for each weight class in Nebraska each year provided by Livestock Marketing Information

Center, Lakewood, CO.

the importance of a relatively high market price to profitability ratio in corn production (Table 3 ). In 2000, corn yield was 20 bushels per acre more than in 2002. However, the 2002 market price for corn was $\$ 0.51$ per bushel more than the 2000 market price and resulted in less than $\$ 6$ per acre more net return in 2000 than in 2002, despite the 20 bushels per acre yield difference (Table 3). The value of corn stalks for winter grazing accounted for as much as $14 \%$ of the net return and may have a higher value during dry years if livestock water is readily available and in competitive locations.

Steers going to grass were nearly $\$ 6$ per 100 pounds more expensive than beef cattle coming off grass (Table 3 ) because of the lower value per pound of the heavier steers (Table 1). The variability in the price differential between steers going to grass and steers coming off grass affected net return. The low price differential allowed 2001 to be nearly $\$ 7$ per acre more profitable than 2000, despite the 147 fewer pounds of beef produced per acre in 2001. Additionally, the low market price in August 2002 ( $\$ 73$ per 100 pounds) reduced the value of cattle coming off grass.

We did not address government price supports, government cost-share programs, or the implications to taxes, soil erosion, wildlife habitat, or carbon sequestration. Although these items are important, they are difficult to quantify broadly and must be addressed for specific situations. Additionally, we did not include the cost to purchase land or interest costs on the loans required to fund the farming operation or purchase livestock.

\section{Implications}

Perennial grass pastures can be profitable in the eastern Great Plains. Big bluestem returned about 2.5 times more dollars per acre than dryland no-till corn grown in eastern Nebraska. These cattle gains are conservative and represent grazing on 
Corn vs Big Bluestem Near Mead, Nebraska

A glyphosate-tolerant corn hybrid (DK 589 RR) was seeded no-till and grown in 0.4 acre dryland plots in 2000, 2001, and 2002 at the University of Nebraska Agricultural Research and Development Center (ARDC) near Mead, Nebraska. Ammonium nitrate fertilizer was applied at 107 pounds of nitrogen per acre. Weeds were controlled with glyphosate. The corn was grown on the same plots each year to represent a continuous corn production system with no crop rotation. "Bonanza" big bluestem was seeded in May 1998 at the ARDC in three 1-acre pastures. The pastures were uniformly cropped in soybeans for 2 years, then seeded no-till (8 pounds of pure live seed per acre) into the soybean stubble. Weeds were managed with herbicides in 1998. Pastures were burned in the spring of 2000 and 2001. No fertilizer was applied in 1998 or 1999 , and no herbicides were applied in 2001. Fertilizer was applied as ammonium nitrate at 100 pounds of nitrogen per acre in 2000, 2001, and 2002. Each 1-acre pasture was stocked with 3 crossbred-yearling steers (650-960 pounds) in midJune 2000, 2001, and 2002. Pastures were grazed continuously until forage use reached about $60 \%$. Soils for the corn and pastures were primarily Sharpsburg silty clay loam.

Corn production, beef production, and market prices were different for each year (Table 1). Costs of production represent actual costs and published custom rates for seeding, fertilizer and herbicide application, and grain harvesting and hauling. All production inputs are presented in dollars per acre (Table 2). No cost was included for drying and storing because many dryland corn producers in eastern Nebraska delay harvest to allow the crop to dry in the field to reduce inputs on less-productive sites. Pasture establishment costs were amortized for 15 years at $5 \%$ interest, and are presented per acre based on an 80-acre pasture. No costs were included in 1998 and 1999 before grazing initiation (because hay could have been harvested) for lost production, livestock transportation costs, or livestock sales commissions. Cattle prices are based on information provided by the Livestock Marketing Information Center (LMIC), Lakewood, CO, and reflect an average of Nebraska markets for June and August in 2000, 2001, and 2002.

only the first growth of big bluestem. The inclusion of latesummer grazing on regrowth could increase the profitability of these perennial pastures. Additionally, the dry June and July in 2001 and 2002 represent the extreme in summer-moisture stress for eastern Nebraska, limiting the corn and pasture production. Big bluestem pastures require sound and moderately intensive management to maintain productivity. Improper management will promote weeds and increase costs. We do not promote planting big bluestem on all cropland in the eastern Great Plains. Dryland corn production is, and will continue to be, an important aspect of diverse agricultural operations in the Great Plains. However, perennial big bluestem pastures provide an excellent alternative to dryland corn on marginal cropland in the eastern Great Plains and provide ancillary benefits, such as reduced soil erosion, increased wildlife habitat, and potential carbon credits from the additional carbon sequestered. Bonanza big bluestem is adapted to Plant Hardiness Zones 4 and 5 in the Tallgrass Prairie region.

Authors are Rangeland Scientist (Mitchell), Research Geneticist (Vogel), and Soil Scientist (Varvel), US Department of Agriculture-Agricultural Research Service, Lincoln, NE 68583-0937; and Animal Scientist (Klopfenstein), Agricultural Economist (Clark), and Extension Forage Specialist (Anderson), University of Nebraska-Lincoln, Lincoln, NE 68583. This article is a joint contribution of the USDA-ARS and the Agricultural Research Division of the University of Nebraska and is published as Journal Series Number 14509. Mention of a product does not imply endorsement by the USDA or the University of Nebraska.

\section{References}

1. [NASS] National Agricultural Statistics Service. 1997. Census of agriculture. Available at: http://www.nass. usda.gov/census/census97. Accessed 28 September 2004.

2. Nebraska Agricultural Statistics Service. 2002. 2002 Nebraska agricultural statistics annual bulletin-prices and economic data. Available at: http://www.nass.usda.gov/ne/ 2002 book. Accessed 28 September 2004.

3. [NOAA] National OcEanic ANd Atmospheric AdminisTRATION. 2003. Annual weather data for Nebraska. Available at http://www5.ncdc.noaa.gov/pdfs/cd/nebraska. Accessed 28 September 2004.

4. Jose, D. H., AND L. J. Brown. 2002. 2002 Nebraska farm custom rates-part I. Lincoln, NE: University of Nebraska Cooperative Extension. Circular EC02-823-A.

5. Nebraska Agricultural Statistics Service. 2002. Nebraska Agri-Facts, Issue 22. Washington DC: USDA, NASS. Available at: http://www.nass.usda.gov/ne. Accessed 28 September 2004.

6. Nebraska Agricultural Statistics Service. 2003. Nebraska Agri-Facts, Issue 1. Washington DC: USDA, NASS. Available at: http://www.nass.usda.gov/ne. Accessed 28 September 2004.

7. Jose, D. H., AND L. J. Brown. 2002. 2002 Nebraska farm custom rates-part II. Lincoln, NE: University of Nebraska Cooperative Extension. Circular EC02-826-A.

8. Wilson, R. K., AND R. T. Clark. 2002. Costs of cattle fencing for grazing areas. Lincoln, NE: University of Nebraska Cooperative Extension. Circular EC02-830.

9. Wilson, R. K., AND R. T. Clark. 2003. Water development costs for grazing livestock. Lincoln, NE: University of Nebraska Cooperative Extension. Circular EC03-821.

\section{Additional Reading}

Alderson, J., AND W. C. Sharp. 1994. Grass varieties in the United States. Washington DC: US Department of Agriculture, Soil Conservation Service. Agriculture Handbook No. 170. 